\title{
ШЛЯХИ ФОРМУВАННЯ ЧИТАЦЬКИХ ІНТЕРЕСІВ МОЛОДШИХ ШКОЛЯРІВ
}

\begin{abstract}
Поміж основних питань,щцо розглядає автор, є визначення теоретичних знань, окреслення умінь, характеристика впрає та етапів, які забезпечують прочес розвитку читачьких інтересів.

Ключові слова: читацькі інтереси, вправи (підготовчо-мотивачійні, репродуктивні, змістовно-інформаційні, творчі, контрольні) та етапи навчання (мотивації та орієнтування; сприймання твору; аналізу тексту; закріплення).

Среди основных вопросов, которые рассматривает автор, является определение теоретических знаний, выделение умений, характеристика упражнений и этапов обучения, которые обеспечивают развитие читательских интересов.

Ключевые слова: читательские интересы, упражнения (подготовительно-мотивационные, репродуктивные, содержательно-информационные, контрольные), этапь обучения (мотивации и ориентировки, восприятия произведения, анализ текста, закрепление).
\end{abstract}

The author investigates the definition of theoretical knowledge, defines the abilities, characterizes exercises and stages, which promote the awakening of readers' interests.

Key words: exercises (preparatory-motivating, reproductive, informative, creative, testing) and stages of teaching (motivation and orientation; comprehension of literary work; text analysis; consolidation).

Зміни в усіх сферах життя безпосередньо впливають на літературну освіту школярів, адже література - це відображення в художньому стилі життя людини та суспільства із складнощами та проблемами. Задля здійснення виховної ролі літератури, слід виробити в учнів уміння читати художні твори, належним чином сприймати дійсність, відображену в художній формі, сформувати прагнення брати приклад із позитивних героїв.

Від початкової школи значно залежить, чи полюблятимуть діти читання, чи, можливо, залишаться байдужими до літератури. Саме у молодших школярів необхідно формувати читацькі інтереси.

Окремі аспекти порушеної проблеми відображено в наукових працях М. Бахтіна, Л. Виготського, Н. Волошиної, Т. Донченко, О. Ісаєвої, А. Копчук, М. Наумчук, С. Пасічника, О. Савченко, Н. Скрипченко, В. Сухомлинського, Г. Ткачук та ін. У роботах науковців обгрунтовано основні вимоги до читання як виду мовленнєвої діяльності, визначено роль класного та позакласного читання в розвитку інтересу до книги, читацької самостійності, шляхи виховання юних читачів та ін.

Аналіз фахової літератури є свідченням проблеми розвитку читацьких інтересів учнів, та 3 одного боку, недостатнього відображення в наукових працях (відсутня достатня кількість відповідних навчально-методичних рекомендацій), а 3 іншого - $\epsilon$ особливо актуальною нині, коли бурхливо розвиваються комп'ютерні технології.

Mema cmammi- запропонувати ефективні шляхи розвитку читацьких інтересів у процесі шкільного навчання.

Вивчення методичної літератури свідчить, що формування читацьких інтересів молодших школярів здійснюється на основі володіння певним колом знань.

Проаналізувавши програму початкової школи, визначено зміст знань, які, на нашу думку, є найефективнішими для пробудження інтересу до читання. Зазначимо, що для їх виокремлення враховано такі змістові лінії програми: робота 3 книгою, усвідомлення жанрових особливостей, смисловий і структурний аналіз творів.

Так, у процесі навчання першокласники практично ознайомлюються 3 титульним листом та його елементами (заголовок, автор, ілюстрація); казками про тварин, загадками, віршами про природу; темою.

Учні другого класу оволодівають такими знаннями: зміст, примітка, авторська збірка, збірка тематична; літературна казка, вірші про людську працю, оповідання, прислів'я, дитячий фольклор (дразнилки, мирилки, лічилки); основна думка.

Третьокласники - зі вступом, анотацією, відомостями про письменника, періодичними виданнями (рік видання, число журналу), довідковою літературою; чарівною та побутовою казкою, байкою, науково-художнім та науково-популярним твором.

Новими для школярів четвертого класу є знання про систематичний, алфавітний, тематичний, жанровий каталоги.

На основі виокремлених елементів книжки (титульний лист, зміст, примітка, анотація), тексту (тема, основна думка) та його жанрової специфіки у школярів розвиваються вміння, розвиток яких визначає основне завдання роботи над формуванням читацьких інтересів.

У початковій школі, як засвідчує аналіз програми, в роботі з читання більша доля припадає на вміння працювати 3 книгою, пізнавати, розрізнювати та називати окремі літературні жанри, розуміти зміст тексту, виконувати творчі завдання на основі прочитаного [4]. Облік якісної сторони сформованості цих умінь дозволяє виявити ті, що вимагають поглиблення.

На прикладі першого класу визначимо, найбільш важливі вміння:

На стадї роботи з книгою розвиваються такі вміння: уважно розглядати книжки на виставці; 
вказувати основні елементи титульного листа (автор, заголовок, ілюстрація); розуміти роль заголовку, ілюстрації у сприйманні книги; пояснювати смисл заголовка; визначати за заголовком й ілюстраціями тему книги; зіставляти малюнки з текстом.

На стадї усвідомлення жанрових особливостей творів: усвідомлювати у змісті казки фантазію; правильно називати героїв казки; знати будову казки (зачин, кінцівка, повтор); відгадувати загадки; розрізнювати вірші про природу та за емоційним забарвленням (веселі, сумні).

На стадї смислового і структурного аналізу творів: розуміти на слух фактичний зміст тексту (хто?, що?, де?, коли?); розрізняти персонажів за характером поведінки (позитивні, негативні); роздумувати над прослуханим (вчинками героїв); визначати тему тексту за допомогою вчителя.

На стадї розвитку творчої діяльності учнів на основі прочитаного: придумувати словесні картини до епізодів; зіставляти зміст малюнків; відшукувати в дитячих бібліотеках за допомогою вчителя, батьків загадки, до прослуханого тексту; добирати ланцюжкові римові слова у віршах.

Отже, зазначені нами знання та уміння - це шлях до розвитку читацьких інтересів молодших школярів.

Практика дозволяє стверджувати, що формування читацьких інтересів можливе за умов планомірної, цілеспрямованої роботи на заняттях у процесі виконання школярами підготовчомотиваційних, репродуктивних, змістовно-інформаційних, творчих та контрольних вправ.

1. Підготовчо-мотиваційні вправи передбачають створення ситуації та мотиву спілкування, первинного уявлення про книги (періодичні видання) або тексту, прогнозування змісту, теми книги (уроку) та ін.

2. Репродуктивні вправи спрямовані на відтворення прослуханого / прочитаного за зразком (повторити інтонацію вчителя; переказувати (розповідати) зміст книги, виразно читати та ін.).

3. Змістовно-інформаційні вправи характеризується аналізом тексту.

4. Творчі вправи пов'язані з творчою діяльністю учнів на основі засвоєних знань та прочитаного тексту.

5. Контрольні вправи спрямовані на перевірку формування читацьких інтересів.

Успіх розвитку читацьких інтересів багато в чому залежить від врахування таких етапів: мотивації й орієнтування; сприймання твору; аналіз тексту; закріплення.

Мета першого етапу «Мотивація та орієнтування» (1-4 класи) полягає в створенні ситуації й мотиву спілкування, первинного сприймання змісту тексту, прогнозування загального характеру; уявленні бібліографічного апарату книжки, бібліотечні прийоми пошуку книг, орієнтування в книжках й т. ін.

Доречними на даному етапі є застосування бесіди у вигля-ді запитань або завдань для виявлення у школярів інтересу до читання нового тексту, орієнтування в книжках та каталогах бібліотеки. Виходячи з цього, продуктивними постають підготовчо-мотиваційні вправи із завданнями на зразок:

1) перегляньте ілюстрації до тексту та відтворіть зміст;

2) визначте тему тексту, обравши одну із двох запропонованих;

3) з'ясуйте тему тексту за пропонованими питаннями:

- Можна дізнатися про книгу з титульної сторінки?;

- розгляньте ілюстрацію та здогадайтеся про зміст книги;

- прочитайте анотацію і скажіть, про що текст;

- прослухайте стислий зміст книжки і здогадайтеся, про що йдеться;

- розгляньте книжки та визначте тему уроку;

- розкажіть про книжку, яку ви читали вдома. 3 яких елементів вона складається;

- як можна відшукати книги в бібліотеці?

Другий етап «Сприймання твору» передбачає прослухування зразка виразного читання вчителем або самостійне виразне читання; розуміння окремих слів, виразів (словникова робота); первинне ознайомлення 3 різними жа-нрами, науково-художніми й науково-популярними творами; удосконалення вмінь самостійно визначати жанрові та інформаційні ознаки творів.

Здійснити цю роботу допомагають репродуктивні вправи. Наприклад: Ви прослухали текст, дайте відповіді на запитання. 1. Який темп використав вчитель - швидкий чи повільний? У якому б темпі ви прочитали цей текст? 2. Назвіть головних героїв. 3. Чи помітили ви щось незвичайне в будові казки?

Третій етап «Аналіз тексту», присвячений повному і точному розумінню змісту тексту. Виходячи 3 цього, на зазначеному етапі, слід використовувати змістовно-інформаційні вправи.

Підкреслимо, що доречним на цьому етапі $є$ використання таких творчих вправ із завданнями: розставте пункти плану в необхідній послідовності; зробіть розмітку тексту для виразного читання; творчо перекажіть текст; прочитайте за ролями; поставте власні запитання до тексту; доберіть ланцюжкові римові слова у віршах; покажіть голосом, мімікою, жестами характер персонажів; заповніть пропуски у прослуханому (прочитаному) тексті; виберіть одне прислів'я, яке найточніше відображає основну думку твору; складіть анотацію до прочитаної книжки (усно).

Останній етап «Закріплення» - спрямований на перевірку здобутих умінь, на якому застосовуваються контрольні вправи завдання-тести, завдання-звіти, практичні завдання. 
Варіант 1.

Завдання-тест.

1. «Колосок»- це казка чи оповідання?

2. Скільки авторів має ця казка?

3. Підкресліть прислів'я, які виражають головну думку казки «Колосок».

Хто рано підводиться, за тим і діло водиться.

Для умілого будь-яка робота $є$ легкою.

На чужу роботу дивитись - ситому не бути.

Варіант 2.

Завдання-звіт.

До теми «Оповідання»: 1) які оповідання ти знаєш?; 2) хто їх автор?; 3) що хвилювало людей, які писали їх?; 4) що ти розкажеш на уроці, щоб усім сподобалося (приклад з оповідання, яке ти обрав)?

Варіант 3.

Практичні завдання.

- Назвіть основні елементи книги, за допомогою яких можна визначити основну інформацію.

- Здогадайтесь про зміст книги за заголовком.

- Знайдіть на сайтах електронних дитячих бібліотек назви книжок схожих за тематикою цієї книжки тощо.

Дослідження вчених (С. Дорошенко, Г. Коваль, А. Копчук, Н. Свєтловська та ін.) вказують на те, що робота 3 формування читацьких інтересів може бути обов'язковою складовою більшості уроків читання - класного та позакласного $[1 ; 2 ; 3 ; 5]$.

Виходячи 3 мети уроків, варто підкреслити, що урок позакласного читання в процесі розвитку читацьких інтересів вимагає достатньо розгорнутої роботи, тому пропонується повний навчальний час; уроки класного читання передбачають попутні завдання, що становлять 3-5 хвилин додаткового часу.

Таким чином, успіх формування читацьких інтересів залежить від володіння учнями знаннями й уміннями; застосування системи вправ (підготовчо-мотиваційних, репродуктивних, змістовноінформаційних, творчих, контрольних) та етапів навчання (мотивації та орієнтування; сприймання твору; аналіз тексту; закріплення).

Стаття не претендує на повний розгляд усіх аспектів окресленої проблеми. Перспективним $є$ питання, які передбачають визначення основних умов роботи з формування читацьких інтересів; пробудження інтересу до книжок на уроках мови.

\section{Література}

1. Коваль Г. П. Методика читання: [навч. посібн.] / Коваль Г. П., Іванова Л. І., Суржук Т. Б. - Тернопіль : Навчальна книга - Богдан, 2010. - 280 с. 2. Копчук А. М. Виховання читацьких інтересів учнів / А. М Копчук. - К. : Т-во «Знання» УРСР, 1985. - 48 с. 3. Методика викладання української мови : [навч. посібн. ] / С. І. Дорошенко, М. С. Вашуленко, О. І. Мельничайко та ін. - К., 1989. - 423 с. 4. Програми для середньої загальноосвітньої школи. 1-4 класи. - К. : Початкова школа, 2006. - 432 с. 5. Светловская Н. Н. Методика внеклассного чтения: [книга для учит.] / Н. Н. Светловская. - [2-е изд., перераб.]. - М. : Просвещение, 1991. $207 \mathrm{c}$. 